\title{
Meta-Analysis the Effect of Combination Oral Contraceptive on the Risk of Venous Thromboembolism and Stroke in Family Planning Acceptors
}

\author{
Putri Yunita Sari'), Eti Poncorini Pamungkasari²), Bhisma Murti') \\ ${ }^{1)}$ Masters Program in Public Health, Universitas Sebelas Maret \\ ${ }^{2)}$ Faculty of Medicine, Universitas Sebelas Maret
}

\section{ABSTRACT}

Background: The global percentage of contraceptive users in women of reproductive age range (15-49 years) or women who are married is $62.7 \%$. Combined oral contraceptives represent $8.8 \%$ of the prevalence (more than 100 million women). COCs are very effective in preventing pregnancy, but like most medications, combined oral contraceptives can be associated with a variety of side effects and risks, including venous thromboembolism (VTE) and stroke. This study aims to determine the estimated effect of combined oral contraceptives on venous thromboembolism and stroke on family planning acceptors by metaanalysis.

Subjects and Method: Meta-analyzes were performed by searching for articles from the Google Scholar, PubMed, Research Gate, Scopus, Springer Link, and Science direct databases. The keywords used in the search for the article included "oral contraceptive" OR "combined oral contraceptives" OR "risk factor" AND "venous thrombolism" OR "VTE" AND "stroke" AND "family planning". The inclusion criteria in this study were full text articles, from 2000-2020, with a case-control study design.
The article analysis was carried out using RevMan 5.3.

Results: There are 15 articles analyzed. The results showed that combined oral contraceptives increased the incidence of venous thromboembolism and stroke in family planning acceptors (aOR 2.95; 95\% CI $=1.80-4.84$; $\mathrm{p}<0.001$ ); (aOR 1.50; 95\% CI $=1.30-1.74$; $\mathrm{p}$ $<0.001$ ). The results of the meta-analysis showed a publication bias between the use of combined oral contraceptives and the incidence of stroke among family planning acceptors.

Conclusion: Combined oral contraceptives affect venous thromboembolism and stroke in family planning acceptors.

Keywords: COCs, venous thromboembolism, stroke, family planning acceptors

\section{Correspondence:}

Putri Yunita Sari, Masters Program in Public Health, Universitas Sebelas Maret. Jl. Ir. Sutami 36A, Surakarta 57126, Central Java. Email: puyunita16@gmail.com. Mobile: 08818794685 .

Cite this as:

Sari PY, Pamungkasari EP, Murti B (2021). Meta-Analysis the Effect of Combination Oral Contraceptive on the Risk of Venous Thromboembolism and Stroke in Family Planning Acceptors. J Matern Child Health. 06(02): 131-145. https://doi.org/10.26911/thejmch.2021.06.02.01.

(c) (1) (-) Journal of Maternal and Child Health is licensed under a Creative Commons Attribution-NonCommercial-ShareAlike 4.o International License.

\section{BACKGROUND}

Venous thromboembolism is a complex multifactorial disease that is influenced by several conditions, both genetic and environmental. Possible conditions include most risks such as surgery and/ or trauma, prolonged immobilization, cancer, myelo- proliferative disorders, and even pregnancy and postpartum. Additional environmental factors that may be associated with an increased risk of venous thromboembolism are body weight, age, smoking status, and hormonal medication. Venous thromboembolism (VTE), which includes deep vein 
thrombosis (DVT) and pulmonary embolism (PE), occurs in 1-2/ 1,000 people per year. The incidence increases with age, from $1 / 100,000$ in children to $1 / 10,000$ in individuals of reproductive age, 1/ 1,000 in individuals aged $50-60$ years, and $1 / 100$ in individuals over 75 years of age (McDaid et al, 2017).

Globally, stroke is the second leading cause of death at over 60 years of age, and the fifth leading cause of death at age 15 to 59 years. Every year, the case fatality rate of stroke worldwide is $40 \%$. Over the past four decades, the incidence of stroke in low and middle income countries has more than doubled. Stroke can cause permanent disability which of course can affect the productivity of the sufferer (Johnson et al, 2016).

Oral contraceptives are an important contraceptive modality and are widely accepted worldwide (Park and Kim, 2013). Combined oral contraceptives are a form of contraception that is safe and effective for most women (Jauch et al, 2013). For most healthy women and nonsmokers, oral contraceptives are safe to use. However, like most drugs, oral contraceptives can be associated with a variety of side effects and risks, including cardiovascular events such as venous thromboembolism (VTE), myocardial infarction, and stroke (Rotermann et al, 2015).

Combined oral contraceptives, introduced more than 6 decades ago, are now used by hundreds of millions of women worldwide and are considered to be the most popular and effective method of contraception. The danger of atherosclerotic and thromboembolic complications in users of hormonal contraceptives is an important and relevant concern for counseling about contraceptive selection. The thrombogenicity of oral contraceptives, especially estrogen compounds, can be associated with the direct effect of estrogen on blood vessel walls and changes in factors that stimulate endothelial dysfunction and also changes in coagulation factors (Heidarzadeh et al, 2014).

Based on the explanation above, the researcher chose to use meta-analysis to expand the application of evidence from the results of previous primary studies, and was able to obtain the strongest empirical causality evidence on the relationship between variables, with a larger sample. Researchers want to conduct a meta-analysis study regarding the use of combined oral contraceptives on the risk of venous thromboembolism and stroke in family planning acceptors.

\section{SUBJECTS AND METHOD}

\section{Study Design}

This was a systematic review and meta-analysis carried out by following the PRISMA flow diagram. Search for articles was carried out through electronic data base media which included: GoogleScholar, PubMed, Research Gate, Scopus, Springer Link, and Science direct. The keywords used in the search for the article were "oral contraceptive" OR "combined oral contraceptives" OR "risk factor" AND "venous thrombolism" OR "VTE” AND "family planning”.

\section{Inclusion Criteria}

The inclusion criteria for articles that can be reviewed are full paper articles with the case control research method, the selected articles are those that display the final results of the adjusted odds ratio (aOR) study, published articles are in English, articles that perform data analysis in multivariate form, an article that examines or discusses risk factors for venous thromboembolism and/ or stroke in a group using COCs with an age range of 15-49 years. 


\section{Exclusion Criteria}

Exclusion criteria for articles included research conducted with cross-sectional, cohorts, and surveys, articles published before 2000, articles published in Mandarin, German, and French, articles featuring bivariate analysis so that the final result displayed was only OR, percent, and the mean difference.

\section{Operational Definition of Variables} The article search was carried out by considering the eligibility criteria defined using the PICO model. The population in the study was family planning acceptors with intervention in the form of combined oral contraceptives, comparison, namely non-users of combined oral contraceptives and outcomes in the form of venous thromboembolism, stroke.

Combined oral contraceptives are oral contraceptives or pills for women that contain a combination of the hormones estrogen and progesterone to prevent pregnancy.

Venous Thromboembolism is the formation of clots in the venous circulation that can result in deep vein thrombosis (DVT) and pulmonary embolism (PE).

Stroke is an acute nervous function disorder caused by a blood circulation disorder in the brain that occurs suddenly (within a few seconds) or rapidly (within a few hours) which causes signs and symptoms according to the disturbed focal area in the brain.

\section{Instruments}

The research stages follow the PRISMA flow diagram and the assessment of the quality of research articles using the Critical Appraisal Skills Program (CASP) for Case Control Study, the Critical Appraisal Checklist for Case Control Study (CEBMa, 2014).

\section{Data Analysis}

The data analysis process in this study was carried out using the Review Manager application (RevMen 5.3), to determine the effect size and heterogeneity of the study. The results of meta-analysis data processing are presented in the form of a forest plot and a funnel plot.

\section{RESULTS}

There are 15 articles with 3 articles from North America, 10 articles from Europe, and 2 articles from Australia. The process of searching for articles is carried out by searching through the database according to PRISMA flow diagrams and can be seen in Figure 1.

Based on the assessment of the quality of the study using the critical appraisal checklist for case control study, the majority of 15 articles included in the quantitative meta-analysis synthesis met the requirements in the assessment of study quality. The following is a table of results from the study quality assessment. 
Sari et al./ Combination Oral Contraceptive on the Risk of Venous Thromboembolism and Stroke

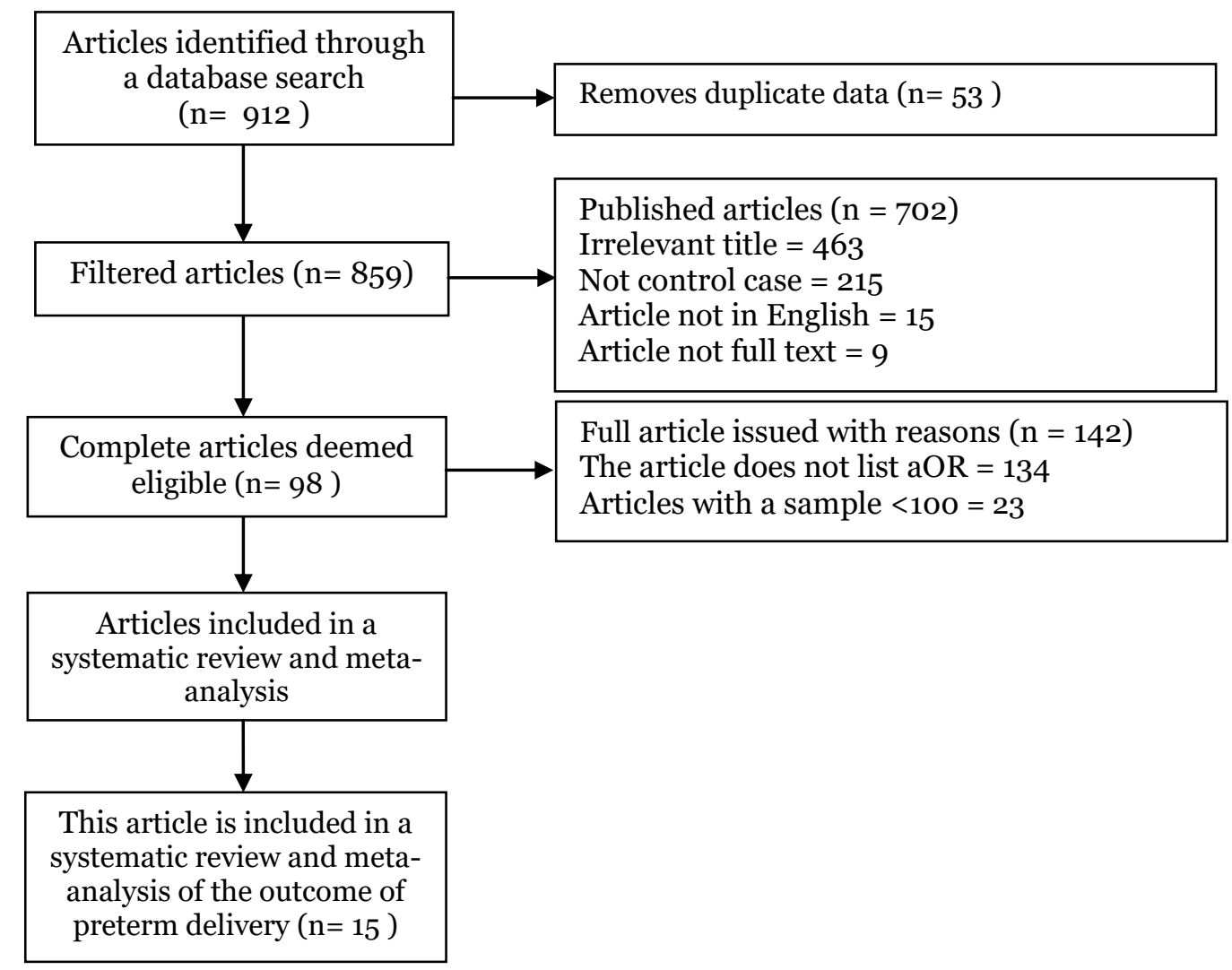

Figure 1. PRISMA flow diagram 
Sari et al./ Combination Oral Contraceptive on the Risk of Venous Thromboembolism and Stroke

Table 1. Assessment of Research Quality using the Critical Appraisal Skills Program for Case Control

\begin{tabular}{|c|c|c|c|c|c|c|c|c|c|c|c|c|c|}
\hline Publication & $\begin{array}{l}\text { Research } \\
\text { focus/ } \\
\text { problem }\end{array}$ & $\begin{array}{l}\text { Research } \\
\text { design }\end{array}$ & $\begin{array}{l}\text { Selection } \\
\text { of research } \\
\text { subjects }\end{array}$ & $\begin{array}{l}\text { Criteria for } \\
\text { selection of } \\
\text { cases and } \\
\text { controls }\end{array}$ & $\begin{array}{l}\text { Compa- } \\
\text { rable } \\
\text { group }\end{array}$ & $\begin{array}{l}\text { Objective } \\
\text { outcome } \\
\text { criteria and } \\
\text { minimize } \\
\text { bias }\end{array}$ & $\begin{array}{l}\text { Data } \\
\text { dred- } \\
\text { ging }\end{array}$ & $\begin{array}{l}\text { Objective and } \\
\text { validated } \\
\text { measurement } \\
\text { methods }\end{array}$ & $\begin{array}{l}\text { Effect } \\
\text { Size }\end{array}$ & $\mathrm{CI}$ & $\begin{array}{l}\text { Confound- } \\
\text { ing factors } \\
\text { not taken } \\
\text { into } \\
\text { account }\end{array}$ & $\begin{array}{l}\text { Whether the } \\
\text { results can be } \\
\text { applied }\end{array}$ & Total \\
\hline $\begin{array}{l}\text { Champaloux et } \\
\text { al, } 2017\end{array}$ & 1 & 1 & 1 & 1 & 1 & 1 & 1 & 1 & 1 & 1 & 1 & 1 & 12 \\
\hline $\begin{array}{l}\text { Kemmeren et al, } \\
2002\end{array}$ & 1 & 1 & 1 & 1 & 1 & 1 & 1 & 1 & 1 & 1 & 1 & 1 & 12 \\
\hline $\begin{array}{l}\text { Pezzini et al, } \\
2006\end{array}$ & 1 & 1 & 1 & 1 & 1 & 1 & 1 & 1 & 1 & 1 & o & 1 & 11 \\
\hline $\begin{array}{l}\text { Siritho et al, } \\
2003\end{array}$ & 1 & 1 & 1 & 1 & 1 & 1 & 1 & 1 & 1 & 1 & 1 & 1 & 12 \\
\hline $\begin{array}{l}\text { Canonico et al, } \\
2016\end{array}$ & 1 & 1 & 1 & 1 & 1 & 1 & 1 & 1 & 1 & 1 & 1 & 1 & 12 \\
\hline Jick et al, 2000 & 1 & 1 & 1 & 1 & 1 & 1 & 1 & 1 & 1 & 1 & 1 & 1 & 12 \\
\hline $\begin{array}{l}\text { Parkin et al, } \\
2011\end{array}$ & 1 & 1 & 1 & 1 & 1 & 1 & 1 & 1 & 1 & 1 & 1 & 1 & 12 \\
\hline Jick et al, 2011 & 1 & 1 & 1 & 1 & 1 & 1 & 1 & 1 & 1 & 1 & 1 & 1 & 12 \\
\hline $\begin{array}{l}\text { Heinemann et } \\
\text { al, } 2009\end{array}$ & 1 & 1 & 1 & 1 & 1 & 1 & 1 & 1 & 1 & 1 & 1 & 1 & 12 \\
\hline $\begin{array}{l}\text { Martinelli et al, } \\
2016\end{array}$ & 1 & 1 & 1 & 1 & 1 & 1 & 1 & 1 & 1 & 1 & o & 1 & 11 \\
\hline $\begin{array}{l}\text { Rodin et al, } \\
2018\end{array}$ & 1 & 1 & 1 & 1 & 1 & 1 & 1 & 1 & 1 & 1 & o & 1 & 11 \\
\hline $\begin{array}{l}\text { Vinogradova et } \\
\text { al, } 2015\end{array}$ & 1 & 1 & 1 & 1 & 1 & 1 & 1 & 1 & 1 & 1 & o & 1 & 11 \\
\hline $\begin{array}{l}\text { Bergendal et al, } \\
2016\end{array}$ & 1 & 1 & 1 & 1 & 1 & 1 & 1 & 1 & 1 & 1 & 1 & 1 & 12 \\
\hline
\end{tabular}

Note: $Y e s=1$, No $=0$ 
Table 2. Overview of primary studies on the effect of combined oral contraceptives on the risk of venous thromboembolism

\begin{tabular}{|c|c|c|c|c|c|c|}
\hline $\begin{array}{c}\text { Author, } \\
\text { year }\end{array}$ & Title & Location & $\begin{array}{c}\text { Study } \\
\text { Design }\end{array}$ & $\begin{array}{c}\text { Simple } \\
\text { Size }\end{array}$ & $\begin{array}{c}\text { Intervention (I) and } \\
\text { Comparator (C) }\end{array}$ & Outcome \\
\hline $\begin{array}{l}\text { Jick et al, } \\
2000\end{array}$ & $\begin{array}{l}\text { Risk of venous thrombo- } \\
\text { embolism among users of third } \\
\text { generation oral contraceptives } \\
\text { compared with users of oral } \\
\text { contraceptives with levonor- } \\
\text { gestrel before and after } \\
\text { 1995: cohort and case-control } \\
\text { analysis }\end{array}$ & America & $\begin{array}{l}\text { Cohort dan } \\
\text { case-control }\end{array}$ & 361.724 & $\begin{array}{l}\text { I: Use of third generation oral } \\
\text { contraceptives (with gestodene } \\
\text { or desogestrel) } \\
\text { C: Use of oral contraceptives } \\
\text { with levonorgestrel }\end{array}$ & $\begin{array}{l}\text { Compared with levonorgestrel } \\
\text { oral contraceptives, third- } \\
\text { generation oral contraceptives are } \\
\text { associated with approximately } \\
\text { twice the risk of venous } \\
\text { thromboembolism. }\end{array}$ \\
\hline $\begin{array}{l}\text { Bergendal et } \\
\text { al, 2014 }\end{array}$ & $\begin{array}{l}\text { Association of Venous } \\
\text { Thromboembolism With } \\
\text { Hormonal Contraception and } \\
\text { Thrombophilic Genotypes }\end{array}$ & Sweden & $\begin{array}{l}\text { Case-control } \\
\text { study }\end{array}$ & 1.850 & $\begin{array}{l}\text { I: Use of combined hormonal } \\
\text { contraceptives } \\
\text { C: Use of progestogen-specific } \\
\text { contraceptives }\end{array}$ & $\begin{array}{l}\text { Thrombophilic genotypes such as } \\
\text { factor V Leiden increase the risk } \\
\text { of venous thromboembolism in } \\
\text { users of combined hormonal } \\
\text { contraceptives. }\end{array}$ \\
\hline $\begin{array}{l}\text { Parkin et al, } \\
2011\end{array}$ & $\begin{array}{l}\text { Risk of venous thrombo- } \\
\text { embolism in users of oral } \\
\text { contraceptives containing } \\
\text { drospirenone or levonor- } \\
\text { gestrel: nested case-control } \\
\text { study based on UK General } \\
\text { Practice Research Database }\end{array}$ & $\begin{array}{l}\text { New } \\
\text { Zealand }\end{array}$ & $\begin{array}{l}\text { Case-control } \\
\text { study }\end{array}$ & 276 & $\begin{array}{l}\text { I: Users of combined oral } \\
\text { contraceptives containing } \\
\text { drospirenone } \\
\text { C: Users of preparations } \\
\text { containing levonorgestrel }\end{array}$ & $\begin{array}{l}\text { Combined oral contraceptives } \\
\text { containing drospirenone have a } \\
\text { higher risk of venous } \\
\text { thromboembolism than } \\
\text { formulations containing } \\
\text { levonorgestrel }\end{array}$ \\
\hline $\begin{array}{l}\text { Jick et al, } \\
2011\end{array}$ & $\begin{array}{l}\text { Risk of non-fatal venous } \\
\text { thromboembolism in women } \\
\text { using oral contraceptives } \\
\text { containing drospirenone } \\
\text { compared with women using } \\
\text { oral contraceptives containing } \\
\text { levonorgestrel: case-control } \\
\text { study using United States } \\
\text { claims data }\end{array}$ & America & $\begin{array}{l}\text { Case-control } \\
\text { study }\end{array}$ & 867 & $\begin{array}{l}\text { I: Use of oral contraceptives } \\
\text { containing drospirenone } \\
\text { C: Use of oral contraceptives } \\
\text { containing levonorgestrel }\end{array}$ & $\begin{array}{l}\text { The risk of non-fatal venous } \\
\text { thromboembolism in users of oral } \\
\text { contraceptives containing } \\
\text { drospirenone is approximately } \\
\text { two times higher than that of oral } \\
\text { contraceptives. }\end{array}$ \\
\hline
\end{tabular}


Sari et al./ Combination Oral Contraceptive on the Risk of Venous Thromboembolism and Stroke

\begin{tabular}{|c|c|c|c|c|c|c|}
\hline $\begin{array}{l}\text { Heinemann et } \\
\text { al, } 2009\end{array}$ & $\begin{array}{l}\text { Use of oral contraceptives } \\
\text { containing gestodene and risk } \\
\text { of venous thromboembolism: } \\
\text { outlook } 10 \text { years after the third } \\
\text {-generation "pill scare" }\end{array}$ & German & $\begin{array}{l}\text { Case-control } \\
\text { study }\end{array}$ & 2.381 & $\begin{array}{l}\text { I: Use of oral contraceptives } \\
\text { containing gestodene } \\
\text { C: Use of second generation } \\
\text { oral contraceptives }\end{array}$ & $\begin{array}{l}\text { Users of oral contraceptives } \\
\text { containing levonorgestrel }\end{array}$ \\
\hline $\begin{array}{l}\text { Martinelli et } \\
\text { al, } 2016\end{array}$ & $\begin{array}{l}\text { Duration of oral contraceptive } \\
\text { use and the risk of venous } \\
\text { thromboembolism. A case- } \\
\text { control study }\end{array}$ & Italy & $\begin{array}{l}\text { Case-control } \\
\text { study }\end{array}$ & 909 & $\begin{array}{l}\text { I: Oral contraceptive users } \\
\text { C: Not using oral } \\
\text { contraceptives }\end{array}$ & $\begin{array}{l}\text { The risk of VTE was not increased } \\
\text { in users of oral contraceptives } \\
\text { containing gestodene compared to } \\
\text { users of oral contraceptives } \\
\text { containing progestins other than } \\
\text { desogestrel and gestodene. }\end{array}$ \\
\hline $\begin{array}{l}\text { Rodin et al, } \\
2018\end{array}$ & $\begin{array}{l}\text { Type of Combined } \\
\text { Contraceptives, Factor V } \\
\text { Leiden Mutation and Risk of } \\
\text { Venous Thromboembolism }\end{array}$ & France & $\begin{array}{l}\text { Case-control } \\
\text { study }\end{array}$ & 2.613 & $\begin{array}{l}\text { I: Use of combined hormonal } \\
\text { contraceptives (CHC) } \\
\text { C: Use of the factor V Leiden } \\
\text { mutation }\end{array}$ & $\begin{array}{l}\text { Thrombophilia disorders are } \\
\text { highly interacting with the } \\
\text { duration of use of oral } \\
\text { contraceptives }\end{array}$ \\
\hline $\begin{array}{l}\text { Vinogradova et } \\
\text { al, } 2015\end{array}$ & $\begin{array}{l}\text { Use of hormone replacement } \\
\text { therapy and risk of venous } \\
\text { Thromboembolism: nested } \\
\text { case-control studies using the } \\
\text { Q Research and CPRD } \\
\text { databases }\end{array}$ & English & $\begin{array}{l}\text { Case-control } \\
\text { study }\end{array}$ & 471.8880 & $\begin{array}{l}\text { I: Hormone replacement } \\
\text { therapy users } \\
\text { C: Not using hormone } \\
\text { replacement therapy }\end{array}$ & in determining VTE \\
\hline $\begin{array}{l}\text { Bergendal et } \\
\text { al, } 2016\end{array}$ & $\begin{array}{l}\text { Risk of venous thrombo- } \\
\text { embolism associated with local } \\
\text { and systemic use of hormone } \\
\text { therapy in peri- and } \\
\text { postmenopausal women and in } \\
\text { relation to type and route of } \\
\text { administration }\end{array}$ & Sweden & $\begin{array}{l}\text { Case-control } \\
\text { study }\end{array}$ & 1.729 & $\begin{array}{l}\text { I: Giving systemic hormone } \\
\text { therapy } \\
\text { C: Administration of estrogen } \\
\text { locally. }\end{array}$ & $\begin{array}{l}\text { The interaction between the use of } \\
\text { FVL and CHC differs according to } \\
\text { the type of progestin, higher in } \\
\text { CHC containing progestin, } \\
\text { drospirenone or third generation } \\
\text { cyproterone acetate, compared } \\
\text { with the second generation. }\end{array}$ \\
\hline
\end{tabular}


Table 3.Primary study descriptions of the effect of combined oral contraceptives on stroke risk

\begin{tabular}{|c|c|c|c|c|c|c|}
\hline $\begin{array}{l}\text { Author, } \\
\text { Year }\end{array}$ & Title & Location & $\begin{array}{l}\text { Study } \\
\text { Design }\end{array}$ & $\begin{array}{l}\text { Simple } \\
\text { Size }\end{array}$ & $\begin{array}{l}\text { Intervention (I)and } \\
\text { Comparator (C) }\end{array}$ & Outcome \\
\hline $\begin{array}{l}\text { Champaloux } \\
\text { et al, } \\
2017\end{array}$ & $\begin{array}{l}\text { Use of combined hormonal } \\
\text { contraceptives among } \\
\text { women with migraines and } \\
\text { risk of ischemic stroke }\end{array}$ & America & $\begin{array}{l}\text { Case-control } \\
\text { study }\end{array}$ & 9,420 & $\begin{array}{l}\text { I: Combined hormonal } \\
\text { contraceptive use with } \\
\text { migraine with aura } \\
\text { C: Use of combined } \\
\text { hormonal contraceptives } \\
\text { with migraine without } \\
\text { aura }\end{array}$ & $\begin{array}{l}\text { The combined effect of combined hormonal } \\
\text { contraception and migraine with aura was } \\
\text { associated with a 6-fold increased risk of } \\
\text { ischemic stroke compared with no risk } \\
\text { factors. The use of combined hormonal } \\
\text { contraceptives does not substantially increase } \\
\text { the risk of ischemic stroke in women with } \\
\text { migraine without aura }\end{array}$ \\
\hline $\begin{array}{l}\text { Kemmeren } \\
\text { et al, } \\
2002\end{array}$ & $\begin{array}{l}\text { Risk of arterial thrombosis } \\
\text { in relation to oral contra- } \\
\text { ceptives (RATIO) study oral } \\
\text { contraceptives and the risk } \\
\text { of ischemic stroke }\end{array}$ & Netherlands & $\begin{array}{l}\text { Case-control } \\
\text { study }\end{array}$ & 1,128 & $\begin{array}{l}\text { I: Use of third-generation } \\
\text { oral contraceptives } \\
\text { (containing desogestrel or } \\
\text { gestodene) C: Use of } \\
\text { second-generation oral } \\
\text { contraceptives } \\
\text { (containing } \\
\text { levonorgestrel) }\end{array}$ & $\begin{array}{l}\text { Third generation oral contraceptives } \\
\text { (containing desogestrel or gestodene) provide } \\
\text { the same risk of ischemic stroke as second } \\
\text { generation oral contraceptives (containing } \\
\text { levonorgestrel) }\end{array}$ \\
\hline $\begin{array}{l}\text { Nightingale } \\
\text { et al, } \\
2004\end{array}$ & $\begin{array}{l}\text { Ischemic stroke in young } \\
\text { women a nested case- } \\
\text { control study using the UK } \\
\text { general practice research } \\
\text { database }\end{array}$ & English & $\begin{array}{l}\text { Case-control } \\
\text { study }\end{array}$ & 1,319 & $\begin{array}{l}\text { I: Use of combined oral } \\
\text { contraceptives } \\
\text { C: Use of hormone } \\
\text { replacement therapy }\end{array}$ & $\begin{array}{l}\text { Risk factors such as hypertension, diabetes, } \\
\text { heart disease, smoking, heavy alcohol } \\
\text { consumption, current COC use, history of } \\
\text { migraines, and history of VTE are associated } \\
\text { with an increased risk of ischemic stroke. }\end{array}$ \\
\hline $\begin{array}{l}\text { Pezzini et al, } \\
2006\end{array}$ & $\begin{array}{l}\text { Inherited thrombophilia and } \\
\text { stratification of ischaemic } \\
\text { stroke risk among users of } \\
\text { oral contraceptives }\end{array}$ & Italy & $\begin{array}{l}\text { Case-control } \\
\text { study }\end{array}$ & 324 & $\begin{array}{l}\text { I: Use of oral contracep- } \\
\text { tives with an inherited } \\
\text { prothrombotic state. } \\
\text { C: Use of oral contracep- } \\
\text { tives with a single } \\
\text { polymorphism }\end{array}$ & $\begin{array}{l}\text { Exposure to the effects of oral contraceptives } \\
\text { may increase the risk of ischemic stroke in } \\
\text { women with an inherited pro-thrombotic } \\
\text { background. }\end{array}$ \\
\hline $\begin{array}{l}\text { Siritho et al, } \\
2003\end{array}$ & $\begin{array}{l}\text { Risk of ischemic stroke } \\
\text { among users of the oral }\end{array}$ & Australia & $\begin{array}{l}\text { Case-control } \\
\text { study }\end{array}$ & 468 & $\begin{array}{l}\text { I: Oral contraceptive } \\
\text { users }\end{array}$ & $\begin{array}{l}\text { There is no evidence of an association } \\
\text { between ischemic stroke and use of low-dose }\end{array}$ \\
\hline
\end{tabular}


Sari et al./ Combination Oral Contraceptive on the Risk of Venous Thromboembolism and Stroke

\begin{tabular}{|c|c|c|c|c|c|c|}
\hline & $\begin{array}{l}\text { contraceptive pill the } \\
\text { melbourne risk factor study } \\
\text { (MERFS) group }\end{array}$ & & & & $\begin{array}{l}\text { C: Not using oral } \\
\text { contraceptives }\end{array}$ & $\begin{array}{l}\text { OCPs (50 g of estrogen) in young Australian } \\
\text { women }\end{array}$ \\
\hline $\begin{array}{l}\text { Canonico et } \\
\text { al, } \\
2016\end{array}$ & $\begin{array}{l}\text { Postmenopausal hormone } \\
\text { therapy and risk of stroke } \\
\text { impact of the route of } \\
\text { estrogen administration and } \\
\text { type of progestogen }\end{array}$ & France & $\begin{array}{l}\text { Case-control } \\
\text { study }\end{array}$ & 15,272 & $\begin{array}{l}\text { I: Use of oral estrogens } \\
\text { C: Use of transdermal } \\
\text { estrogens }\end{array}$ & $\begin{array}{l}\text { Taken together with the findings for } \\
\text { thrombotic risk, trans-dermal estrogens } \\
\text { alone or in combination with micronized } \\
\text { progesterone may be the best option for } \\
\text { increasing the benefit / risk ratio of HT use } \\
\text { and may be the safest option with respect to } \\
\text { the risk of VTE and stroke. }\end{array}$ \\
\hline
\end{tabular}




\section{Forest plot}

\section{Venous Thromboembolism}

Interpretation of the results of the primary research meta-analysis process the effect of combined oral contraceptives on venous thromboembolic infection can be seen in the forest plot. Based on the results of the analysis in Figure 3, it can be seen that 9 articles report that combined oral contraceptives are one of the risk factors that influence the incidence of venous thromboembolism in family planning acceptors. Meanwhile, there was high heterogeneity between primary studies $\left(I^{2}=91 \%\right.$; $<0.001)$. Thus, the Random Effect Model is used. In the data analysis in the forest plot, the use of combined oral contraceptives increased the incidence of venous thromboembolism by 2.95 times the risk compared with those who did not use COCs, and was statistically significant (aOR 2.95; 95\% CI = 1.80-4.84; $\mathrm{p}<0.001)$.

\section{Stroke}

Interpretation of the results from the metaanalysis process of primary research on the effect of combined oral contraceptives on stroke on family planning acceptors can be seen in the forest plot. Based on the results of the analysis in Figure 4, it can be seen that as many as 6 articles report that combined oral contraceptives are one of the risk factors that influence stroke incidence in family planning acceptors. Meanwhile, there was no heterogeneity between primary studies $\left(\mathrm{I}^{2}=38 \%\right.$; $\left.\mathrm{p}<0.001\right)$. Thus, the Fixed Effect Model is used. In data analysis in the forest plot, the use of combined oral contraceptives increased the incidence of stroke by 1.50 times the risk of those who did not use COCs, and was statistically significant (aOR 1.50; 95\% CI = 1.30-1.74; $\mathrm{p}<0.001$ ).

\section{Funnel Plot}

\section{Venous Thromboembolism}

A funnel plot is a plot that depicts the estimated effect size of each study on the estimate of its accuracy which is usually the standard error. Based on Figure 4, the funel plot of the effect of combined oral contraceptives on the incidence of venous thromboembolism shows that there is no publication bias which is indicated by the symmetries seen between the distance of the primary study on the right and left of the funnel plot, and the number of studies between the left and right funnel plots that are balanced.

\section{Stroke}

A funnel plot is a plot that depicts the estimated effect size of each study on the estimate of its accuracy which is usually a standard error. Based on the 6 funel plot figure, the effect of COCs on the incidence of stroke indicates a publication bias characterized by asymmetry. Judging by the distance of the primary study on the right and left of the funnel plot, it does not form an inverted funnel and the number of studies between the left and the right is not balanced. On the right side there are 4 plots which are located close together, on the left side there is 1 plot, and there is 1 plot in the middle. 
Sari et al./ Combination Oral Contraceptive on the Risk of Venous Thromboembolism and Stroke

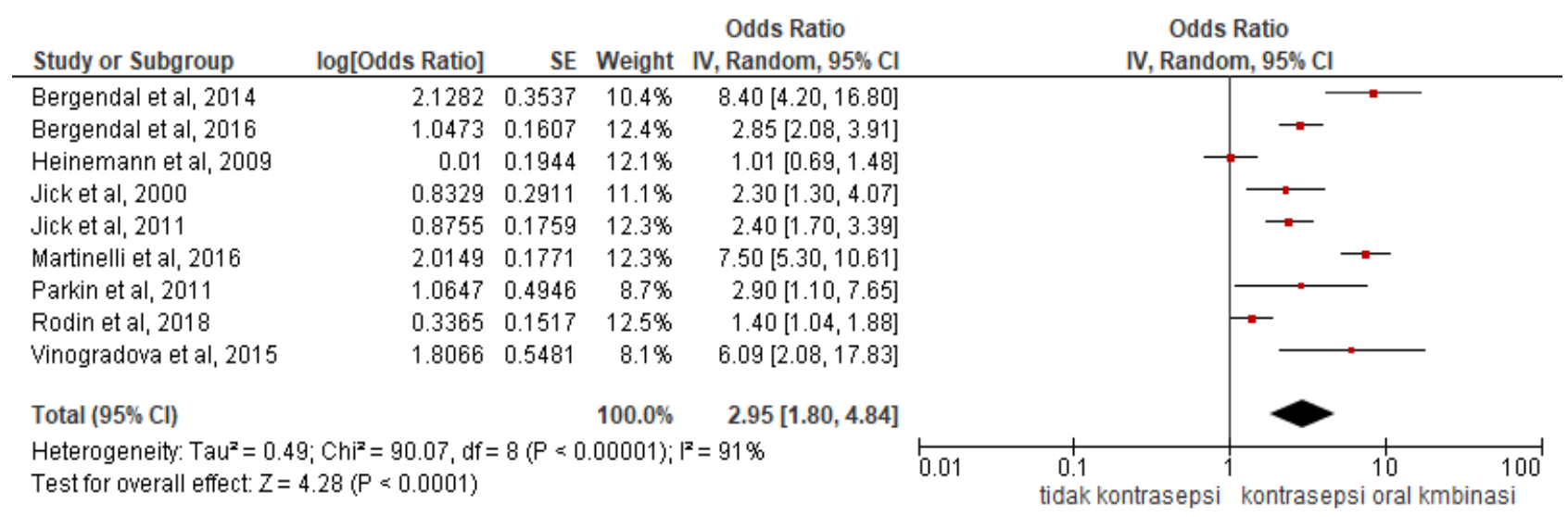

\section{Figure 3. Forest plot of COCs against venous thromboembolism}

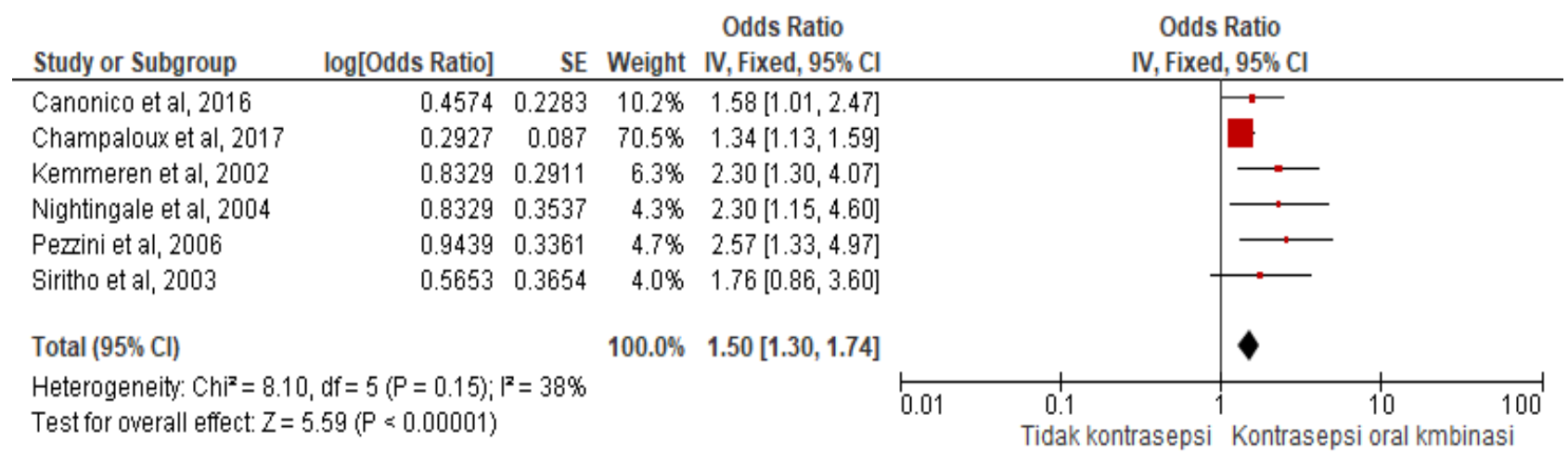

Figure 4. Forest plot of COCs against stroke

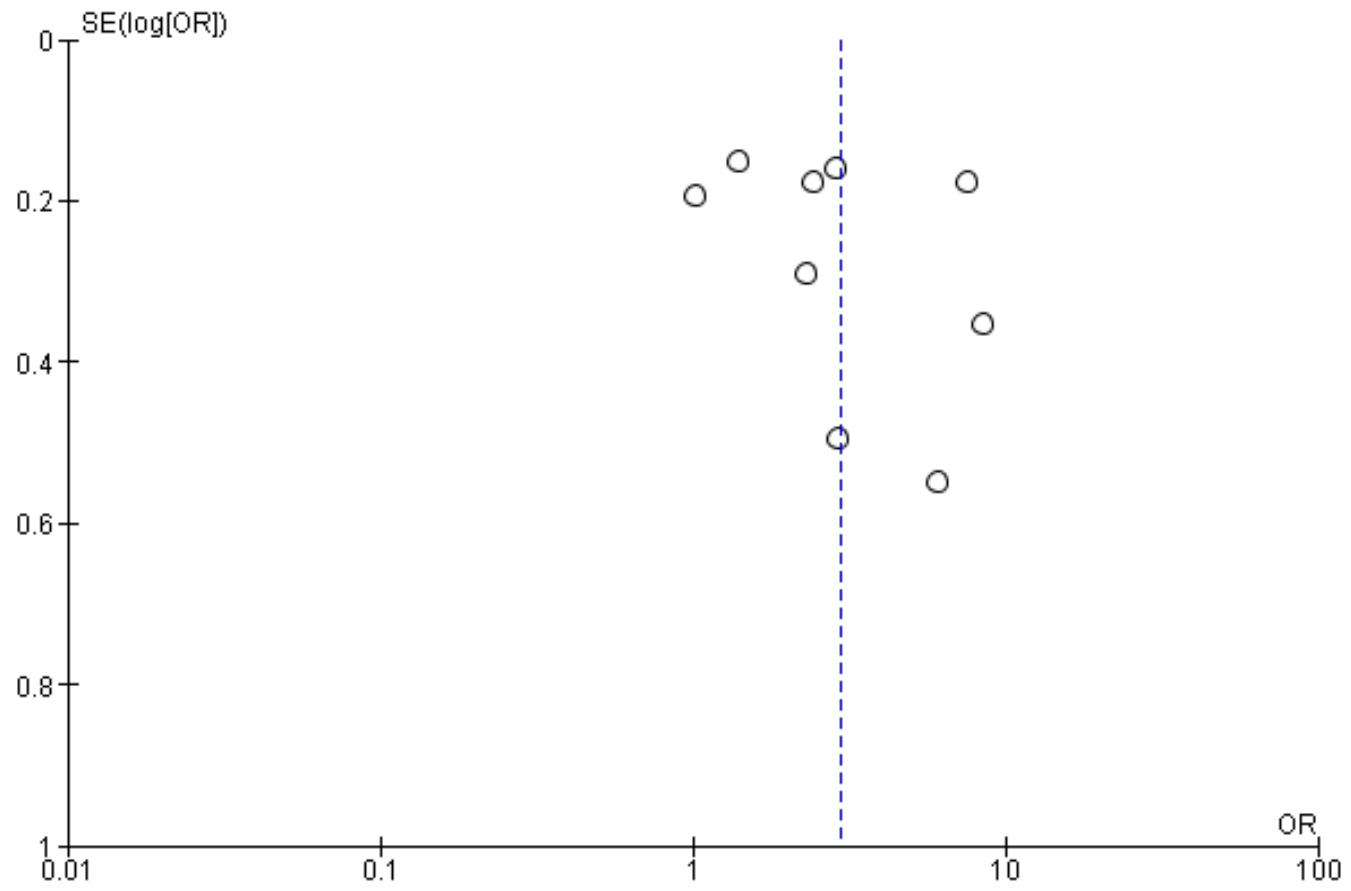

Figure 5. Funnel plot of the effect of COCs on venous thromboembolism 


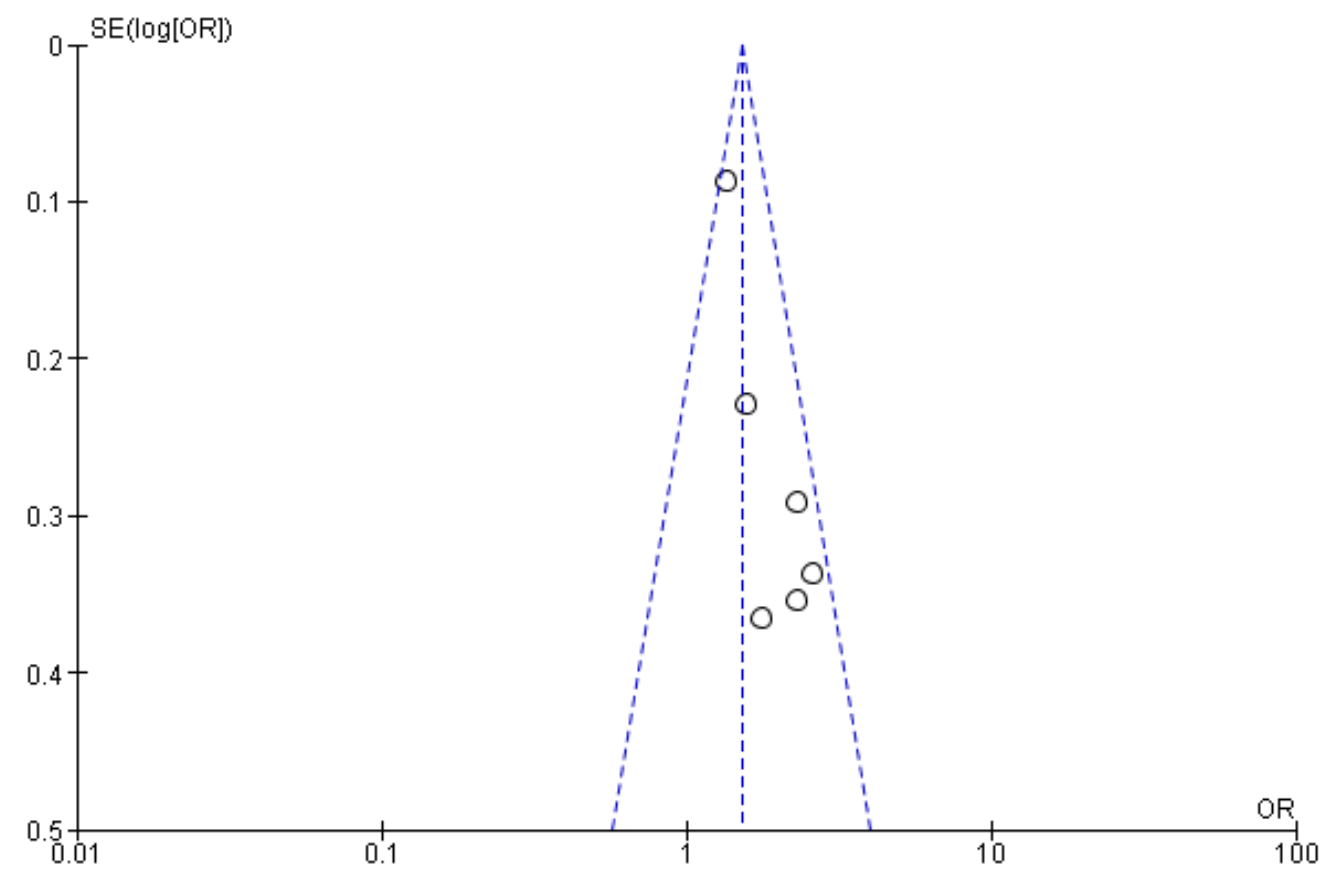

Figure 6. Funnel plot of the effect of COCs on stroke

\section{DISCUSSION}

Cardiovascular disease is the leading cause of death in Europe, the proportion of all deaths due to cardiovascular disease is substantially greater among women (51\%) than men (42\%) (Nichols et al, 2014). Coronary heart disease (CHD), stroke, and venous thromboembolism (VTE), which consists of deep vein thrombosis (DVT) of the limbs and potentially fatal sequelae pulmonary embolism (PE), are major cardiovascular disorders (Lowe, 2004).

Hormonal contraception is a matter of scientific importance and is relevant for counseling women about contraceptive choice. Several studies have assessed the risk of venous thromboembolism associated with the use of newer hormonal contraceptive products (past 10 years) but few studies have examined thrombotic stroke and myocardial infarction, and the results of available studies have been conflicting (Lidegaard et al., 2012). Over the years, it has been shown that COC use is positively associated with the risk of VTE. This increased risk of VTE was highest during the first year of use. This can vary according to the characteristics of different COCs, such as estrogen dose, molecule, and type of progestin (Rodin et al, 2014).

Stroke in women is a major health problem. More than half of all strokes occur in women and women account for nearly $60 \%$ of stroke-related deaths. The current generation of oral contraceptives may be associated with an increased risk of stroke. However, the absolute risk is small (less than pregnancy-related death). Women over 35 years of age who use oral contraceptives, especially women with hypertension, smoking, or migraines, appear to be the group at greatest risk of stroke. Several guidelines suggest against using oral contraceptives in this group (Brass, 2004).

Systematic review and meta-analysis in this study were conducted with the aim of studying and estimating the magnitude of the effect of combined oral contraceptives on venous thromboembolism and stroke on family planning acceptors from various similar studies. In this research, systematic review and meta-analysis used 
research that controlled for confounding factors, which could be seen from the inclusion requirements of the study, namely multivariate analysis and the statistical result reported was the adjusted odd ratio (aOR). The results of systematic review and meta-analysis are presented in the form of forest plots and funnel plots. The forest plot in the meta-analysis results shows visually the amount of variation (heterogeneity) (Akobeng, 2005 in Murti, 2018). The funnel plot shows the relationship between the effect size of the study and the sample size of the various studies studied that can be measured in different ways (Murti, 2016). The funnel plot shows the effect size on the sample size, the funnel plot can be used to determine publication bias from the results of a meta-analysis study from a combination of several primary studies. If the dots form an inverted funnel with a wide base, while the direction of the plot is narrower and the points between the right and left are balanced, this indicates that there is no publication bias. Conversely, if the dots show an asymmetric shape between the right and left halves, publication bias can be suspected (Ahn and Kang, 2018).

Studies related to the effect of combined oral contraceptives on the incidence of venous thromboembolism and stroke on family planning acceptors consists of 15 articles from 10 articles in the continent of Europe, 3 articles in the Americas, and 2 articles in the Australian continent.

\section{Combined oral contraceptives against venous thromboembolism}

Based on the results of the analysis of 9 articles regarding the effect of combined oral contraceptives on venous thromboembolism, it is reported that combined oral contraceptives are one of the risk factors that influence the incidence of venous thromboembolism in family planning acceptors. Meanwhile, there was high heterogeneity between primary studies (I2 = 91\%; $\mathrm{p}<0.001)$. Thus, the Random Effect Model is used. The data analysis in the forest plot showed that combined oral contraceptives can increase the incidence of venous thromboembolism by 2.95 times compared to those without combined oral contraceptives, and statistically significant ( $\mathrm{p}<0.001)$.

The results are supported by Parkin et al. (2011) that current users of oral contraceptives containing drospirenone increased approximately twofold the risk of non-fatal idiopathic venous thromboembolism compared to users of oral contraceptives containing levonrgestrel. Vinogradova et al. (2015) shows that the risks associated with COCs other than norgestimate are higher for newer pill preparations than for the second-generation pill. Jick et al. (2000) showed that third-generation oral contraceptives were associated with a twofold risk of venous thromboembolism compared with oral contraceptives with levonorgestrel.

\section{Combined Oral Contraceptives Against Stroke}

Based on the analysis of 6 articles regarding the effect of combined oral contraceptives on stroke, it can be seen that combined oral contraceptives are one of the risk factors that influence the incidence of stroke in family planning acceptors. Meanwhile, there was no heterogeneity between primary studies $\left(\mathrm{I}^{2}=38 \%\right.$; $\left.\mathrm{p}<0.001\right)$. Thus, the Fixed Effect Model is used. Data analysis in the forest plot showed that combined oral contraceptives increased the incidence of stroke by 1.50 times the risk of those without combined oral contraceptives, and was statistically significant ( $p$ $<0.001)$.

Results supported by Kemmeren et al. (2002) show that third-generation oral contraceptives (containing drosperinone, 
desogestrel or gestodene) provide the same risk of first ischemic stroke as secondgeneration COCs (containing levonorgestrel). The results of a meta-analysis study (Xu et al, 2015) show that data from observational studies on current use of modern COCs is associated with an increased risk of first-time ischemic stroke. Combined oral contraceptives that contain lower doses of estrogen tend to contribute to a smaller increased risk of ischemic stroke. Meanwhile, a study conducted (Siritho et al, 2003) showed that there was no evidence of an association between ischemic stroke and the use of low-dose COCs in young women in Australia. Other modifiable risk factors such as hypertension, diabetes mellitus and smoking are also important to note.

\section{AUTHOR CONTRIBUTION}

Putri Yunita Sari is the main researcher who selects the topic, explores and collects research data. Eti Poncorini Pamungkasari and Bhisma Murti played a role in analyzing data and reviewing research documents.

\section{CONFLICT OF INTEREST}

There is no conflict of interest in this study.

\section{FUNDING AND SPONSORSHIP}

This study is self-funded.

\section{ACKNOWLEDGEMENT}

We are very grateful to the database providers, namely GoogleScholar, PubMed, Research Gate, Scopus, Springer Link, and Science direct.

\section{REFERENCE}

Ahn E, Kang H (2018). Introduction to systematic review and meta-analysis: A health care perspective. Korean J Anesthesiol. 71(2): 1-38.

Brass LM (2004). Estrogens and stroke: Use of oral contraceptives and postmenopausal use of estrogen: Current recommendations. Curr Treat Options Neurol. 6(6): 459-467. https://doi.org/10.1007/s11940-004-0004-9.

Hugon-Rodin J, Gompel A, Plu-Bureau G (2014). Mechanisms in endocrinology: Epidemiology of hormonal contraceptives-related venous thromboembolism. Eur J Endocrinol. 171(6): R221-R230. https://doi.org/10.1530/EJE-14-0527.

Jauch EC, Saver JL, Adams HP, Bruno A, Connors JJB, Demaerschalk BM, Khatri $P$, et al. (2013). Guidelines for the early management of patients with acute ischemic stroke: A guideline for healthcare professionals from the American Heart Association/American Stroke Association. J Am Heart Assoc. 44(3): 870-947. https://doi.org/10.1161/STR.obo13e318284056a.

Jick H, Kaye JA, Vasilakis-scaramozza C, Jick SS (2000). General practice 1995: cohort and case-control analysis. British Med J. 321: 1190-1195.

Johnson W, Onuma O, Owolabi M, Sachdev S (2016). Stroke: A global response is needed. Bulletin of the World Health Organization.94(9): 634A-635A. https://doi.org/10.2471/BLT.16.181636.

Kemmeren JM, Tanis BC, Van Den Bosch MAAJ, Bollen ELEM, Helmerhorst FM, Van Der Graaf Y, Rosendaal FR, AlgraA (2002). Risk of arterial thrombosis in relation to oral contraceptives (RATIO) study: Oral contraceptives and the risk of ischemic stoke. Stroke.33(5): 12021208. https://doi.org/10.1161/o1.STR.o000015345.61324.3F.

Lidegaard Ø, Løkkegaard E, Jensen A, Skovlund CW, Keiding N (2012). Thrombotic stroke and myocardial infarction with hormonal contraception. N Engl J Med.67(10): 640-641. https://doi.org/10.1097/01.ogx.0000422965.64164.ac

Lowe GDO (2004). Hormone replacement therapy and cardiovascular disease: 
Sari et al./ Combination Oral Contraceptive on the Risk of Venous Thromboembolism and Stroke

Increased risks of venous thromboembolism and stroke, and no protection from coronary heart disease. JIntern Med.256(5): 361-374. https://doi.org/10.1111/j.1365-2796.2004.01400.x.

McDaid A, Logette E, Buchillier V, Muriset M, Suchon P, Pache TD, Tanackovic G, et al. (2017). Risk prediction of developing venous thrombosis in combined oral contraceptive users. PLoS ONE. 12(7): 1-12. https://doi.org/10.1371/journal.pone.0182041.

Murti B (2016). Prinsip dan metode riset epidemiologi. Karanganyar: Bintang Fajar Offset.

Park H, Kim K (2013). Associations between oral contraceptive use and risks of hypertension and prehypertension in a cross-sectional study of Korean women. BMC Women's Health. 13(1). https://doi.org/10.1186/1472-6874-13-39.

RotermannM, Dunn S, Black A (2015). Oral contraceptive use among women aged 15 to 49: Results from the canadian health measures survey. Public Health Rep. 26(10): 21-28.

Siritho S, Thrift AG, McNeil JJ, You RX, Davis SM, Donnan GA (2003). Risk of ischemic stroke among users of the oral contraceptive pill: The Melbourne Risk Factor Study (MERFS) Group. Stroke. 34(7): 1575-1580. https://doi.org/10.1161/01.STR.0000077925.16041.6B.

Vinogradova Y, Coupland C, Hippisley-CoxJ (2015). Use of combined oral contraceptives and risk of venous thromboembolism: nested case-control studies using the QResearch and CPRD databases. BMJ (Clinical Research Ed.), 350: 2135. https://doi.org/10.1136/bmj.h2135.

Xu Z, Li Y, Tang S, Huang X, Chen T (2015). Current use of oral contraceptives and the risk of first-ever ischemic stroke: A meta-analysis of observational studies. Thromb Res.136(1): 52-60. https://doi.org/10.1016/j.thromres.2015.04.02 1. 